\title{
CyPRIAN NorWid WOBEC PARNASIZMU W ŚWIETLE SWOICH WYPOWIEDZI
}

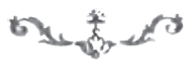

$\mathrm{R}$

EFLEKSJA POETYCKA NoRWIDA - mimo swojej ponadczasowości i uniwersalności - czerpała niezwykle silnie z kultury francuskiej, w której bliskości powstało jego opus magnum. Jak twierdzi historyk literatury francuskiej Claude Pichois, jeśli mówi się o poezji drugiej polowy XIX wieku we Francji, określa się ją mianem parnasistowskiej, gdyż ten nurt był wtedy dominujący ${ }^{1}$. Przypomnijmy, że założeń parnasistowskiego modelu poezji można doszukać się już we wstępie do Les Orientales (1829) Victora Hugo, a przede wszystkim w przedmowie do Panny de Maupin (1835) Théophile'a Gautiera². Jako preparnasistowskie można określić dzieła poetyckie Théodore'a de Banville'a z lat czterdziestych i pięćdziesiątych (np. Les Cariatides, Les Stalactites, Les Odelettes), Gautiera (Émaux et Camées, 1852 i wyd. nast.) oraz Leconte'a de Lisle'a (Poèmes antiques, 1852, Poèmes barbares, 1862). Powstały one, zanim w 1866 roku wydano Le parnasse contemporain: recueil de vers nouveaux (stąd wziął nazwę ten nurt poetycki). Pod koniec 1850 roku Norwid napisał między innymi traktat o sztuce Promethidion ${ }^{3}$ oraz w latach 1865-1866 uporządkował i uzupełnił cykl Vade-mecum, zbudowany z „poetyckich perełek", powstających w latach 1847-1866.

1 Zob. C. Pichois, Littérature française. Le romantisme, t. 2: 1843-1869, Paris 1979, s. 317.

2 Zob. tamże, s. 324.

3 Według Zbigniewa Sudolskiego trudno ustalić czas powstania utworu, jednak większa część poematu została napisana w drugiej połowie 1850 roku. Zob. Z. Sudolski, Norwid. Opowieść biograficzna, Warszawa 2003, s. 172. 
Rozpatrywanie twórczości Norwida bez uwzględnienia kontekstu kultury francuskiej staje się zatem niepełne i niewystarczające, by mówić o wartości i oryginalności dzieła artystycznego polskiego poety. Badacze zwracali uwagę przede wszystkim na związki twórczości Norwida z kulturą anglosaską, włoską czy niemiecką ${ }^{4}$. Mniej eksplorowane były natomiast związki z kulturą francuską, mimo że to we Francji właśnie Norwid spędził znaczną część swego życia. Historycy literatury, którzy wykazywali tego typu pokrewieństwa, jak Kazimierz Wyka w swej wydanej w 1948 roku pracy Cyprian Norwid. Poeta i sztukmistrz, poruszyli zaledwie pewne wątki, które nie zostały w pełni zbadane. Juliusz Wiktor Gomulicki zwrócił uwagę na zależności między twórczością Norwida i Charles’a Baudelaire’a (cytowanego przez Norwida w Albumie Orbis) oraz Gautiera5; temat ten podjął Maciej Żurowski, nie przedstawiając jednak całościowego ujęcia problemu ${ }^{6}$. Związki Norwida z Baudelairem poruszały też Alicja Lisiecka i Maria Delaperrière 7 . Problem relacji twórczości Norwida i poezji parnasistowskiej ukazuje także Wiesław Rzońca, stwierdzając, że w twórczości autora Vade-mecum można odnaleźć różnorodne wpływy, a nawet naśladownictwo Gautiera i Banville’a. Można też dostrzec wiele wspólnych wątków z poezją Leconte’a de Lisle’a, między innymi kosmogeniczność rozważań czy tłumaczenie pism starożytnych. Od prekursorów parnasizmu francuskiego różni zaś Norwida stanowiące o oryginalności występowanie w jego twórczości pierwiastków pozytywizmu i te-

4 Zob. m.in.: A. van Nieukerken, Ironiczny konceptyzm. Nowoczesna polska poezja metafizyczna w kontekście anglosaskiego modernizmu, Kraków 1998; A. Brajerska-Mazur, Los geniuszów, czyli niezwykłe paralelizmy w życiu i twórczości Gerarda Manleya Hopkinsa i Cypriana Kamila Norwida, w: Symbol w dziele Norwida, pod red. W. Rzońcy, Warszawa 2011; K. Samsel, Norwid-Conrad. Epika w perspektywie modernizmu, Warszawa 2015; S. Rzepczyński, Wokół nowel „włoskich” Norwida. Z zagadnień komunikacji literackiej, Słupsk 1996; R. Fieguth, Norwid und die deutsche Kultur, w: Suche die Meinung. Karl Dedecius, dem Übersetzer und Mittler, zum 65. Geburtstag, hrsg. von E. Grözinger, A. Lawaty, Wiesbaden 1986; H.R. Jauss, Przedmowa do pierwszego niemieckiego wydania „Vade-mecum“ C. Norwida, przeł. M. Kaczmarski, „Studia Norwidiana" 1985/1986, nr 3-4.

5 Zob. J.W. Gomulicki, Wstęp, w: C. Norwid, Czarne kwiaty. Białe kwiaty, Warszawa 1965, s. 43; Norwid - poeta europejski (w 75. rocznicę śmierci), „Nowa Kultura” 1958, nr 22.

6 Zob. M. Żurowski, Norwid i Gautier, w: Nowe studia o Norwidzie, pod red. J.W. Gomulickiego i J.Z. Jakubowskiego, Warszawa 1961, s. 168-19o.

7 Zob. A. Lisiecka O baudelairyzmie „Vade-mecum”, „Twórczość” 1968, nr 3, s. 77-89, M. Delaperrière, Norwid i Baudelaire: zbliżenie przez sztuke, w: Od tematu do rematu. Przechadzki z Balcerzanem, red. T. Mizerkiewicz i A. Stankowska, Poznań 2007. 
matów religijnych ${ }^{8}$. Według Anety Mazur zjawisko parnasizmu należy łączyć przede wszystkim z poetyką tekstów, a elementy tego nurtu można odnieść do twórczości wielu poetów polskich w latach 1863-1914; badaczka uznaje Norwida za patrona „polskiego parnasizmu”, nie analizując jego utworów, ponieważ uważa, że jest to twórczość w większym stopniu różniąca się od nurtu parnasistowskiego w poezji polskiej niż do niego zbliżona ${ }^{9}$.

Jeśli parnasizm w poezji polskiej drugiej połowy XIX wieku jest mimo wszystko zjawiskiem marginalnym, skoncentrowanym na pięknie formalnym, to parnasizm francuski - powtórzmy opinię Pichois - dominował w poezji francuskiej tego okresu, był niezwykle złożonym i szerokim zjawiskiem literackim, którego głównym założeniem było wcielanie w sztukę i przez sztukę wartości i ideałów. Korespondencja Norwida staje się szczególnym świadectwem związku poety z życiem literackim Francji drugiej połowy XIX wieku. Listy poety mówią wiele o relacjach jego myśli z rozważaniami o literaturze i szerzej - sztuce, które formułowano we Francji drugiej połowy XIX wieku. Szczególnie interesujące - a do tej pory raczej całościowo niepodejmowane - wydają się odniesienia poety wobec francuskiego parnasizmu ${ }^{10}$. Autor Vade-mecum czytał skupiające parnasistów czasopismo "L'Artiste”, w którym ukazywały się między innymi utwory Banville’a ${ }^{11}$ oraz parnasistowski manifest L'Art ${ }^{12}$ i inne utwory Gautiera ${ }^{13}$ (od 1856 roku redaktora periodyku). Także na łamach czasopisma „L’Artiste” w 1856 roku Gautier wyrażał wiarę w autonomię sztuki:

8 Zob. W. Rzońca, Premodernizm Norwida - na tle symbolizmu literackiego drugiej połowy XIX wieku, Warszawa 2013, s. 96-115.

9 Zob. A. Mazur, Parnasizm w poezji polskiej II połowy XIX wieku i początku XX wieku, Opole 1993, s. 45.

10 Maria Grzędzielska uważa, że pojęcie „parnasu polskiego” jest niejednoznaczne i odnosi się przede wszystkim do kunsztu artystycznego, a Norwida nie można łączyć z tym nurtem ze względu na jego nowatorstwo. Poeta mógł widzieć lub czytać zbiory Leconte'a de Lisle’a Poèmes et poésies (1855) i Poèmes barbares (1862). Badaczka dostrzega zbieżności w postrzeganiu utylitaryzmu między Lecontem de Lislem, Gautierem i Norwidem, odwołując się do wstępu do Vade-mecum. Zob. M. Grzędzielska, Cyprian Norwid i parnas polski, „Studia Norwidiana 1984, t. 2, s. 29-44.

11 Zob. m. in. Th. Banville, Hérodiade, „L'Artiste” 1856, t. 2, s. 93; Th. Banville, Ma maladie, „L'Artiste” 1857, t. 2, s. 234.

12 Pierwodruk utworu został zamieszczony w "L’Artiste” (1857, nr z 13 IX, s. 29) pod tytułem À M. Théodore de Banville. Réponse à son „Odelette”. W nieco zmienionej formie i pod innym tytułem: L’Art, ukazał się w edycji Émaux et Camées z 1858 roku.

13 Zob. m. in. Th. Gautier, L'Aveugle, „L'Artiste” 1856, t. 2, s. 9; Th. Gautier, À une robe rose, „L'Artiste” 1850, t. 4, s. 125. 
Wierzymy w autonomię sztuki; Sztuka dla nas nie jest środkiem, ale celem. Każdy artysta, który ma na celu inną rzecz niż piękno, nie jest w naszych oczach artystą, nie mogliśmy nigdy zrozumieć oddzielenia idei od formy, tak samo jak nie zrozumiemy ciała bez duszy, albo duszy bez ciała [...] piękna forma jest piękną ideą, bo na cóż byłaby forma, która nie wyraża niczego? ${ }^{14}$

O tym, że czasopismo było znane Norwidowi, dowiadujemy się z listu do Leonarda Chodźki z 1866 roku, w którym poeta pisze: „[...] śliczny dziennik [«L'Artiste»] listem swego administratora do mnie pisanym uświadomił mię, że przyjmuje trzy moje miedzioryty" ${ }^{15}$. Inne odniesienie do francuskiego periodyku pojawia się w liście do Ludwika Nabielaka z 1868 roku: „[...] gdyby Ci się podobało $\mathrm{w}$ pierwszym lepszym cabinet de lecture zażądać tomu lutowego i marcowego de „L'Artiste” [...]. Jest to revue najstarszy w Europie pod względem sztuki: w lutowym jest moja Sybilla, komp[onowana]-rys[owana]-ryta przeze mnie; w marcowym głowa Sforzy w więzieniu [...]" (IX: 359) ${ }^{16}$.

Wzmianki w listach Norwida dowodzą, że poeta znał profil i czas powstania francuskiego periodyku oraz interesował się ukazującymi się tam artykułami. We wskazanym w liście numerze „L'Artiste” z lutego 1868 roku można znaleźć także sądy na temat Sztuki (pisanej wielką literą) ${ }^{17}$. Tendencja do wywyższania sztuki jest obecna również w twórczości Norwida, na przykład w Promethidionie: „O sztuko! - człowiek do ciebie powraca / Jak do cierpliwej matki dziecię smutne [...] O! sztuko - Wiecznej tęczo Jeruzalem” (III: 427) ${ }^{18}$ oraz w zbiorze Vade-mecum: „[...] poezja albowiem jako siła wytrzymuje wszelkie warunki czasów, ale nie wytrzymuje ich zarówno jako sztuka” (II: 10). Tylko twórczość, niezależna od wszelkiego piętna politycznego, wolna od odniesień do jakiejś sytuacji czy zdarzenia, a więc niezastygła w konkretnym miejscu i czasie, może zdaniem poety nosić miano sztuki prawdziwej i pełnej, gdyż jest uniwersalna i żywa dla odbiorcy.

14 Th. Gautier, Introduction, „L’Artiste” 1856, t. 3, s. 4. Jeśli nie zaznaczono inaczej, tłumaczenia tekstów i tytułów z języka francuskiego pochodzą ode mnie - A.K.

15 C. Norwid, Listy 1862-1872, w: tegoż, Pisma wszystkie, zebrał, tekst ustalił, wstępem i uwagami krytycznymi opatrzył J.W. Gomulicki, Warszawa 1971, t. 9, s. 226. Dalej cytaty z Norwida podawane są za wydaniem Pism wszystkich i oznaczone cyfrą rzymską (tom) i arabską (strona).

16 Zob. też listy z 1868 roku do: do Łucji Rautenstrauchowej (IX: 345), Augusta Cieszkowskiego (IX: 351), do Bronisława Zaleskiego (IX: 366, 369), 512). Sybilla zatytułowana została Figure de caractère („L'Artiste” 1868, t. 6, s. 304); Głowa Sforzy w więzieniu zaś - Le Prisonnier: „L'Artiste” 1868, t. 6, s. 454.

17 A. Houssaye, Le style antique et italien dans la peinture flamande et hollandaise, "L'Artiste” 1868, nr z 1 II, s. 156.

18 Wstęp do Promethidiona jest datowany najwcześniej na 1850 rok (por. przyp. 3). Zob. też: III: 761 . 
Związki sztuki ze sferą sacrum najpełniej chyba zostały zaakcentowane przez Norwida w poemacie Promethidion. Sztuka, nazwana „tęczą Jeruzalem" (III: 427), jawi się jako przymierze zesłane przez Boga i umożliwiające odbiorcy już za życia kontakt z sacrum. Podobnie w Kolebce-pieśni (Do spótczesnych ludowych pieśniarzy) czytamy: „Stąd to nie są NASZE - PIEŚNI NASZE - / lecz Boskiego coś bierą w się" (II: 115), czy w wierszu Pióro - że poezja jest „czarodziejską zdrojów Mojżeszowych laską” (I: 49). Twórczość staje się więc, jak zauważa Stefan Sawicki, „czymś, co w tajemniczy sposób, ale z Bożej woli krzepi spragnionych w ich wędrówce do Ziemi Obiecanej" ${ }^{19}$.

Dla parnasistów francuskich sztuka także była rodzajem modlitwy przynoszącej ulgę, zapomnienie, duchową odnowę odbiorcy. Takie przekonanie wyrażał między innymi Leconte de Lisle, kultywując swoistą religię piękna, będącą przejawem ścisłego związku między absolutem i sferą estetyki ${ }^{20}$. W poezji Banville’a, szczególnie w zbiorze Améthystes, ważny punkt odniesienia stanowił także zwrot ku niebu, ku temu, co pozaziemskie. Wspólne są również dla autora Kolebki-pieśni i poetów francuskich - między innymi - przekonania o przynależności sztuki do świata idei (Sully Prudhomme, Les Stances et poèmes) czy o powiązaniu boskiej proweniencji sztuki z wartościami takimi jak dobro, szczerość, prawda (Sully Prudhomme, Stances et poèmes; Banville, Les Cariatides) oraz łączenie jej boskiego charakteru z uniwersalizmem (Banville, Les Stalactites).

W twórczości Norwida można dostrzec zbieżność poglądów na temat sztuki flamandzkiej z koncepcjami Arsène’a Houssaye'go, jednego z parnasistów publikujących także w Le Parnasse contemporain z 1866 roku. Podobieństwo to dotyczy interpretacji malarstwa Rembrandta. W noweli Bransoletka czytamy o tym, że „Linię znał Rafael [...] . Rembrandt zaś odkrył i objawił głęboką światła tkliwość i mistyczną logikę" (VI: 35). Grażyna Halkiewicz-Sojak podkreśla w swoim artykule: „Zestawienie z Rafaelem zyskuje tutaj odmienną waloryzację w porównaniu z dotychczasowymi sensami podobnych opozycji. Holenderski malarz zostaje uznany za tego, który w pospolitej twarzy potrafi odnaleźć i pokazać ślad głębokiej duchowości” ${ }^{21}$.

Ta odmienność w spojrzeniu Norwida może wynikać z inspiracji poety sądami Houssaye'go, który w swoim artykule Rembrandt, opublikowanym

19 S. Sawicki, Wstęp do: C. Norwid, Wiersze, Lublin 1991, s. 34.

20 Zob. P. Flottes, Leconte de Lisle. L'homme et l'oeuvre, Paris 1954, s. 147.

21 G. Halkiewicz-Sojak, Między karczmą a salonem - Norwid o sztuce flamandzkiej i... polskiej, w: Norwid - artysta. W 125. rocznice śmierci poety, pod red. K. Trybusia, W. Ratajczaka, Z. Dambek, Poznań 2008, s. 62. 
W „L'Artiste” z 1847 roku, także zwrócił uwagę na filozoficzny aspekt malarstwa Rembrandta: „[...] u Rembrandta to, co promienieje, to myśl i światło”, „Rembrandt to myśl i analiza” 22 - napisał Houssaye. Co prawda, Norwid nie przebywał w 1847 roku w Paryżu, lecz jak wynika z listu, który zostanie zacytowany niżej, będąc w innych krajach Europy, zapoznawał się z treścią czasopism francuskich.

Innym czasopismem, które czytał Norwid, było „Revue des deux mondes”. W nim również ukazywały się utwory parnasistów. W trzecim tomie z 1843 roku (wiemy z innych listów, że Norwid czytał w Wenecji numer drugi z tego roku - zob. VIII: 337) znajduje się wzmianka o cyklu Cariatides Banville’a ${ }^{23}$. $\mathrm{W}$ trzecim tomie $\mathrm{z} 1853$ roku na łamach tego pisma ukazał się artykuł Gustave'a Planche'a La Poésie et les poètes en France en 1853, uwzględniający twórczość Leconte’a de Lisle'a ${ }^{24}$, którego poezje zostały zamieszczone w 1855 roku. Tutaj też 1 czerwca 1855 roku opublikowano osiemnaście wierszy cyklu Les Fleurs du Mal Charles'a Baudelaire’a ${ }^{25}$, którego twórczość w początkowym okresie należy łączyć z parnasizmem. Wreszcie w latach 1843-1870 (z przerwami) na łamach przeglądu publikowano regularnie poezje Sully'ego Prudhomme'a ${ }^{26}$.

W liście do Michała Kleczkowskiego z 1858 roku czytamy: „Żebyś wiedział, czego to o mnie od tylu lat nie pisano, a nawet i po francusku! Raz, pamiętam, w Wenecji, weszedłszy do cabinet de lecture, biorę do ręki «Revue des Deux Mondes» i znajduję o literaturze północnej, a dalej moje nazwisko, przez Francuza, z którym nigdy nie gadałem! - przez Xavier Marmier, jeżeli się nie mylę" (VIII: 337). Numer czasopisma, o którym wspominał Norwid, pochodzi z 1843 roku, a w artykule La Russie en 1842. Varsovie et Pologne sous le régime russe (Rosja w 1842. Warszawa i Polska pod panowaniem rosyjskim) Xavier Marmier w ten sposób charakteryzował polskiego poetę: „Norwid, młody jeszcze autor zbioru ludowych poematów i poezji ulotnych, odznaczający się porywczym natchnieniem i świeżością wyobraźni; podróżuje teraz po Niemczech i Włoszech, zauważyliśmy, że jego podróże przyczyniły się do nowego rozkwitu jego talentu poetyckiego" ${ }^{27}$.

22 A. Houssaye, Rembrandt et son école, "L'Artiste” 1847, t. 8, s. 65.

23 Ch. Labitte, Poetae minores, „Revue des deux mondes” 1843, t. 3, s. 127.

24 G. Planche, La Poésie et les poètes en France en 1853, „L'Artiste” 1853, t. 3, s. 1194.

25 Ch. Baudelaire, Fleurs du mal, „Revue des deux mondes” 1855, t. 10, s. 1079.

26 S. Prudhomme, Poésies intimes, „Revue des deux mondes” 1870, t. 87, s. 1009.

27 X. Marmier, La Russie en 1842. Varsovie et la Pologne sous le régime russe, „Revue des deux mondes" 1843 , t. 2, s. 50. 
Przy okazji warto dodać, że w tomie drugim „Revue des deux mondes” Z 1843 roku znajduje się artykuł Le Salon de 1843 Louisa Peisse’a ${ }^{28}$, w którym mowa o dziele malarskim, „o takiej sile, by mogło istnieć samodzielnie, dzięki swojej wartości, a o jego tryumfie niech decyduje tylko powab sztuki" ${ }^{29}$. Wspomniana już idea autonomii sztuki, wpisana w program estetyczny parnasistów i zawarta także w tym artykule, mogła więc również zainspirować autora Promethidiona, czego przykłady znajdujemy w jego dziełach, a także w pisanych nieco później w Paryżu listach. W liście do Marii Trębickiej z września 1866 roku Norwid czyni następującą uwagę: „Pieśń jest nie tylko sztuka i kwiat, ale dzieło [...] to niedelikatność najświętsza - proszę o nią a są delikatności takie, co z Olimpu pogańskiego, gdzie już bogi tylko [...]” (VIII: 287).

Zarówno więc w wypowiedziach francuskich parnasistów, jak i - Norwida (zawartych w jego twórczości literackiej i epistolografii) sztuka była traktowana jako doskonały twór istniejący niezależnie od człowieka; jej zadaniem było uchwycenie ogólnych praw rządzących światem, zawsze przy tym aktualnych. Właśnie taką poezję - skierowaną też do „późnego wnuka” - tworzył Norwid. Ponadto w ujęciu Norwida rozpadowi podlega cała koncepcja języka odjednostkowego, który jest niezdolny, by wyrazić myśli i rzeczy przez słowo, jak bowiem pisze Michał Kuziak: „[...] w konsekwencji poeta wykorzystuje wiele różnych języków zderzonych, konwersujących często na zasadzie swobodnego montażu" ${ }^{30}$. Sztuka samowystarczalna oznaczałaby więc niepodporządkowanie opisowi konkretnych realiów rzeczywistości, wykraczanie poza nie, sytuowanie się ponad tym, co czasowe, aby można było uchwycić to, co uniwersalne.

We fragmencie poematu Wita-Stosa pamięci estetycznych zarysów siedem, zatytułowanym Manieryzm (w znaczeniu: przyzwyczajenie), sztuka, jak zauważa Rolf Fieguth, zostaje „spłycona przez wirtuozerstwo i manieryzm” ${ }^{31}$, bo człowiek odciska na niej zbyt duże piętno i przez to dostrzegamy twórcę, nie zaś samą sztukę. Kategoria „bezosobistości” jest więc charakterystyczna dla dzieła Norwida, który głosił, że sztuka powinna koncentrować się przede

28 L. Peisse, Le salon de 1843, „Revue des deux mondes” 1843, t. 2, s. 85.

29 Tamże, s. 256.

30 M. Kuziak, Poeta trudny. Tezy o idiomatyczności Norwida (na marginesie interpretacji), w: Trudny Norwid, pod red. P. Chlebowskiego, Lublin 2013, s. 88, zob. też: W. Toruń, Wokół Norwidowskiej koncepcji słowa, Lublin 2003.

31 R. Fieguth, Symbolizmy w Quidamie, w: Symbol w dziele Cypriana Norwida, pod red. W. Rzońcy, Warszawa 2011, s. 89. 
wszystkim na ukazywaniu prawdy o rzeczywistości ${ }^{32}$. Podobnie w koncepcji parnasistów francuskich sztuka miała zostać zdepersonalizowana, zobiektywizowana, gdyż tylko taka mogła nosić miano prawdziwej ${ }^{33}$. W poezji Banville’a (w zbiorze Les Cariatides) występuje wiele odwołań do poezji jako sztuki niezależnej od twórcy, istniejącej samodzielnie, której artysta jest jedynie wyrazicielem. Podobnie idea samoistnie żyjącego dzieła pojawia się między innymi w wierszu Je me croyais poète (Uważałem się za poetę) Sully'ego Prudhomme'a. W twórczości Leconte'a de Lisle'a, w przedmowie do zbioru Poèmes antiques w pełni i bezpośrednio została wyrażona idea sztuki niezaangażowanej we współczesne wydarzenia.

W liście z 1869 roku poeta wyraża swoje opinie na temat UŻYTECZNOścI w sztuce, która była także jedną z zasadniczych kwestii poruszanych przez parnasistów:

Poezja, która zapomina, o tym, że ona coś RoBIĆ powinna - - zapomina przez to samo o zdrowej estetyce. Ja takiej poezji nie rozumiem DLA TEGO SAMEGO, DLA CZEGO BARDZO PIĘKNA KOBIETA W CHINACH NIE MOŻE SIĘ RUSZYĆ Z MIEJSCA, BO MA OTYŁE FORMY, I NIE MOŻE NIC RĘKĄ DOTKNĄĆ, BO MA PALCÓW KSZTAŁTY ZEPSOWANe KonSERWACJą PALCóW I baŁWOCHWALSTWEM PAZnoKCI! Ale Nausika, córka królewska u Homera, DLATEGO JEST TAKA PIĘKNA, IŻ DO RZEKI CHODZI PRAĆ BIELIZNĘ!... [...] JEST PEWNA PROPORCJA UTYLITARNOŚCI, KTÓRA JEST WARUNKIEM PIĘKNA.

(IX: 403)

Chińska metaforyka listu Norwida przywodzi skojarzenie z przedmową do Panny de Maupin Gautiera, choć w tym ostatnim dziele została ona inaczej zwaloryzowana. Poeta francuski pisał bowiem: „Od pewnej wazy, która mi służy, wolę wazon chiński usiany smokami i mandarynami, który nie służy mi do niczego [...]" ${ }^{34}$. Autor podkreśla tym samym, że użyteczność niszczy prawdziwą sztukę. Waza, której się używa, zatraca charakter dzieła sztuki, ponieważ nie podziwia się jej, a jedynie się z niej korzysta. W przedmowie do wydanego w 1833 roku wznowienia pierwszych poezji Albertus ou L’Ame et le péché Gautier pisał, że kiedy jakaś rzecz nabiera wartości użytkowej, traci swoje piękno, swoją wolność, gdyż zostaje przypisana konkretnej funkcji i z poezji staje się prozą ${ }^{35}$.

Nie o takim jednak rodzaju utylitaryzmu pisał Norwid. Wskazuje on w liście jedynie na pewną dozę utylitaryzmu, nie zaś na podporządkowanie

32 W. Rzońca, dz. cyt., s. 99.

33 E. Rivaroli, Poétique parnassienne d'après Théodore de Banville, Paris 1915, s. 159.

34 T. Gautier, Panna de Maupin, przeł. i wstępem opatrzył T. Żeleński (Boy), Warszawa 1958, s. 52.

35 Zob. Th. Gautier, Préface, w: tegoż, Euvres. Poésies, Paris 189o, s. 5. 
się idei użyteczności, które zresztą sam odrzucał, między innymi we wstępie do Vade-mecum pisząc, że należy „poezję polską zwolnić od służb i atrybutów czasowo jej właściwych" (II: 10). Dla Norwida poezja, która niczemu nie służy, nie może być piękna, bo w pojęciu piękna zawiera się zawsze pierwiastek użyteczności.

We wspomnianej Pannie de Maupin Gautiera, podobnie jak w liście Norwida, można również odnaleźć wykład idei użyteczności przez analogię do życia kobiety: „Na co służy piękność kobiet? Byleby kobieta była, z punktu widzenia lekarskiego, dobrze ukształtowana i zdolna rodzić dzieci, zawsze będzie dość dobrą dla panów ekonomistów" "36. Gautier zwraca uwagę na fakt, że nie można patrzeć na świat jedynie w kategoriach zysku i ekonomii bez nawiązania do potrzeb, uczuć, godności człowieka. Norwid w swoim liście pokazuje drugi biegun obserwacji świata jedynie w kategoriach czystego piękna. Nie oznacza to jednak, że występuje przeciwko hasłu „sztuki dla sztuki”, które, jak można zaobserwować na przykładzie Gautiera, było wieloaspektowe. Dla francuskiego poety, podobnie jak dla Norwida, postulat „sztuki dla sztuki” nie oznaczał więc twórczości skupionej jedynie na formie i jednocześnie błahej, lecz zaangażowanej w wyrażanie tego, co najbliższe uczuciom i moralności wyzwolonej od krępujących norm społecznych ${ }^{37}$.

Za inny przejaw analogii z parnasizmem można uznać pojawiające się w korespondencji Norwida określenie artysty jako RZEMIEŚLnika (list do Kazimierza Wójcickiego z marca 1860 roku): „JAKO CZŁOWIEK rozgrzewam się pamięcią S[zanowne]go Wójcickiego, ale JAKo I RZEMIEśLNIK posyłam rysunek tu włączony, aby nie zostawić w dzienniku samej tylko dziewiętnastoletniej próbki” (VIII: 412). Taka wizja artysty-rzemieślnika przywołuje na myśl znany z Promethidiona wizerunek twórcy jako profesjonalisty, co zostaje zapisane w jednym ciągu zawodów: „kamieniarz, cieśla, mularz, snycerz" (III: 444). Praca artysty była według Norwida działalnością taką, jak każda inna, to znaczy wymagającą wysiłku i poświęcenia. Zostaje to pod-

T. Gautier, Panna de Maupin, s. 51-52.

37 Widoczne jest to m.in. w wierszu Gautiera La Mansarde: „Voilà longtemps que le poète, / Las de prendre la rime au vol, / S'est fait reporter de gazette, / Quittant le ciel pour l'entresol" (Th. Gautier, Émaux et camées, Paris 1954, s. 123). W wolnym przekładzie: „Już od dawna poeta / znużony chwytaniem rymów w locie / staje się sprawozdawcą gazet / porzuca niebo dla antresoli”. Tytuł wiersza La Mansarde oznacza poddasze, strych; to w takim miejscu tworzył kiedyś artysta. Był to jednocześnie pewien symbol życia twórczego z dala od prozy życia i blisko Boga. Jednak teraz rzeczywistość jest inna. Poeta musi pracować i brać udział w życiu społecznym, czyli przenieść się bliżej społeczeństwa i jego spraw: do antresoli (Zob. French literature series, ed. B. Norman, University of South Carolina 1997, t. 21, s. 69). 
kreślone także w liście do Józefa Bohdana Zaleskiego: „Cała sztuka wyszła z koryta swego - pracy ludzkiej błogosławieństwem nie jest - TAK, JAK JEST - jest niepotrzebna! A że mimo tego jest - to ogromny dowód, ile potrzebna!..." (VIII: 120).

Podobną koncepcję sztuki można odnaleźć także w traktacie Banville’a.: „Słowo «Poezja» [...] pochodzi od greckiego słowa «robić», «wytwarzać», "produkować» $[\ldots]$ ".. ${ }^{38}$. Stąd wynikało postrzeganie artysty jako jednostki posiadającej pewne zawodowe przygotowanie. Pisanie nie wypływało, tak jak u romantyków z natchnienia, lecz było świadomym i sukcesywnym procesem wymagającym pracy twórczej: „Poeta musi przestrzegać wiernie najbardziej ścisłych reguł gramatyki. Aby nie zniknąć i nie stać się głupcem, leniem, niezrozumialcem, musi poddać się regułom gramatycznym w większym stopniu, niż gdyby był najbardziej rasowym i najdoskonalszym prozaikiem" 39 .

Norwid również wypowiadał się na temat zdobywania wiedzy przez poetów, podzielał bliski Banville’owi pogląd na semantykę ortografii; na przykład: w Dwóch guzikach ( $z$ tyłu), wierszu powstałym pod wpływem dyskusji na temat ortografii i ortofonii, prowadzonych z Julianem Fontaną w 1866 roku $^{40}$ : „Lecz mowa-piękna zawsze i wszędzie polega / Na wygłoszeniu słowa zarazem ponętnie / I tak zarazem, że się znowu pisownię postrzega" (II: 127). W tym samym roku w liście do Juliana Fontany Norwid akcentował natomiast konieczność zachowania pewnej hierarchii w myśleniu o sztuce: „[...] poświęcać chcesz wyższe formy i prawa formom niższym i prawom podrzędnym. Jeszcze się nikomu nie śniło o gramatyce, kiedy już były arcydzieła - Homer był!!! [...] Owszem - powołaniem stanowczym arcydzieł jest być NIEUSTANNIE PO-NAD-GRAMATYCZNYmi [...]” (IX: 209). Elementy stricte gramatyczne były więc dla polskiego poety, jak się wydaje, jedynie tłem twórczości, której cel stanowiło wyrażanie idei. Język w tej koncepcji był narzędziem, za pomocą którego możliwe stało się ich uzewnętrznienie.

Jak można zauważyć, Norwid podejmował identyczne kwestie jak parnasiści francuscy w tamtym czasie, a także używał podobnych przenośni nie zawsze identyczne były konkluzje. Warto w tej kwestii zwrócić uwagę na METAFORYKĘ RZEŹBIARSKĄ lub szerzej, jak wskazuje Kazimierz Wyka, na „wyobraźnię rzeźbiarską”, obecną w listach oraz twórczości Norwida ${ }^{41}$ : „W doskonałej liryce powinno być jak w odlewie gipsowym: zaCHOWANE

38 Th. de Banville, Petit traité de poésie française, Paris 1872, s. 5.

39 Tamże, s. 57.

40 Zob. II: 391; Z. Sudolski, dz. cyt., s. 411.

41 Zob. K. Wyka, Cyprian Norwid. Studia, artykuty, recenzje, Kraków 1989, s. 7-66. 
POWINNY BYĆ I NIE ZGŁADZONE NOŻEM TE KRESY, GDZIE FORMA Z FORMĄ MIJA SIĘ I POZOSTAWIA SzPARY. Barbarzyniec tylko zdejma te nożem z gipsu i psowa całość” (IX: 328). Tak pisał Norwid w Paryżu w 1867 roku, ale są też wcześniejsze odwołania do rzeźby. W 1852 roku w korespondencji poety na początku wywodu dotyczącego ironii czytamy: „Dłuto wyciosujące twarz Anioła z marmuru zgrzyta gorzko..." (VIII: 186). Ten sam obraz zgrzytającego dłuta znajduje się w utworze Ironia oraz w Quidamie ${ }^{42}$. Motyw „dłuta” jest też obecny między innymi w utworze Wita-Stosa pamięci estetycznych zarysów siedem (III: 534), w wierszu Lapidaria (II: 223) czy w wielu innych ogniwach Vade-mecum, oprócz wspomnianej już Ironii, na przykład w utworach Posag i obuwie (II: 20), Styl nijaki (II: 10o), Fortepian Szopena (II: 144).

Metaforyka rzeźbiarska (związana z ideą transposition d'art) ujawnia się także w innych utworach parnasistów, między innymi w wierszu La mort du poète (Śmierć poety) z cyklu Cariatides Banville'a czy w utworze La coupe (Kielich) z cyklu Poèmes antiques Leconte'a de Lisle’a. Szczególne znaczenie nadał jej jednak Gautier w zbiorze Émaux et camées. W wierszu-manifeście poetyckim Gautiera L’Art dłuto również pełni bardzo ważną funkcję jako narzędzie pracy artystycznej:

\section{Sculpte, lime, cisèle; \\ Que ton rêve flottant \\ Se scelle \\ Dans le bloc résistant! ${ }^{43}$}

Poza utworem L'Art występuje też w innych utworach tego tomu (np. Le poème de la femme nosi podtytuł Marbre de Paros - Marmur z Paros). Ponadto do zbioru wchodzi składający się z dwóch części utwór Étude de mains (Studium rąk), zawierający refleksje na temat rzeźby.

W okresie przemian ekonomicznych i przemysłowych we Francji drugiej połowy XIX wieku wzrosło znaczenie PRACY RĘCZNEJ; powstawały liczne ateliers ${ }^{44}$. Poetyckim tego wyrazem są wspomniane odniesienia w twórczości parnasistów francuskich zwracających uwagę na manualne aspekty wytwarzania sztuki. Kreację artystyczną, jak w programowym wierszu Gautiera, porównywali do dłutowania, cyzelowania, rzeźbienia. Podobnie w twórczości polskiego poety, u którego wielokrotnie pojawia się kwestia

42 Zob. tamże, s. 21.

43 Th. Gautier, Émaux et camées, Paris 1954, s. 133. W wolnym przekładzie: „Rzeźb, wygładzaj, dłutuj / Aby twoje ulotne marzenie / Utwierdziło się / W skale, która przetrwa!".

44 Zob. P. Moreau, Le romantisme, Paris 1962, s. 373. 
pracy nad dziełem za pomocą narzędzi rzeźbiarskich, by wytworzyć najdoskonalszą formę manualnej twórczości, co jednak nie oznacza tu twórczości po parnasistowsku „wycyzelowanej”, „bez szpar” i „pęknięć”, gdyż „W doskonałej liryce powinno być jak w odlewie gipsowym” (II: 328). Doskonałość u Norwida jest więc tożsama $\mathrm{z}$ nieuchwytną ideą, dla której forma jest jedynie fundamentem, niezbędnym by zaistnieć, ale niewystarczającym, by ukazać się w pełni; zadaniem sztuki jest wykraczanie poza to, co materialne.

Biorąc pod uwagę fakt, że Norwid zajmował się rzeźbiarstwem, odwołania do tej dziedziny twórczości wydają się naturalne. Należy jednak podkreślić, że jeśli poeta studiował rzeźbę już we Florencji, czyli od roku 1842, to wspomnianych metafor na większą skalę zaczął używać dopiero w okresie paryskim ${ }^{45}$. Wtedy też pojawił się w jego twórczości motyw dłuta - być może pod wpływem styczności z twórczością parnasistów francuskich, u których metafory rzeźbiarskie pojawiały się bardzo często. Podobnie, wątek pracy artysty nad dziełem nasila się w twórczości Norwida od czasu pobytu w Paryżu, co prawdopodobnie również należy łączyć z oddziaływaniem tego nurtu we francuskiej poezji.

Kolejną ważną kwestią, która nasuwa się, gdy porównujemy wypowiedzi Norwida o poezji z refleksjami parnasistów francuskich, jest RYM. Polski poeta wspomina o nim w Paryżu w 1869 roku przy okazji refleksji na temat swojej twórczości: „Pisałem za żywota w rymie, co było ogólną własnością i zaletą” (IX: 432). Norwid dostrzegał rolę rymu także wcześniej, na przykład w 1866 roku, kiedy w liście do Józefa Ignacego Kraszewskiego pisał, że: „Poezja polska tam pójdzie, gdzie główna część Vade-mecum wskazuje sensem, tokiem, rymem i przykładem” (IX: 218), następnie w liście do Henryka Merzbacha zaznaczał, że „Vade-mecum złożone ze 100 rymów ${ }^{46}$ najwszelakszej budowy" (IX: 228). Norwid nie napisał, że Vade-mecum złożone jest ze stu wierszy, stu liryków czy stu utworów - lecz ze stu rymów. Uwypuklił tym samym znaczenie rymu, który jest nie tylko ornamentem brzmieniowym, lecz integralną częścią filozofii jego dzieła. Rym może bowiem nie tylko poszerzać rozumienie utworów poetyckich, a także wskazywać zupełnie nowe ich odczytanie. Tak jak w wierszu Finis rym podkreślający związek z florą: zielnik - śmiertelnik, umożliwia skojarzenie słowa „śmiertelnik” z nazwą

Wcześniej, tzn. przed okresem paryskim, metafory związane z rzeźbą występują sporadycznie, pojawiają się, m.in. w wierszu Marmur - biały oraz Burza [I].

46 „Rym” oznaczał także wiersz rymowany. Zob. Słownik języka polskiego pod. red. S. Lindego, t. 3, Warszawa 1812 (hasło „rym”). 
kwiatu „nieśmiertelnik” " ${ }^{7}$. Interpretacja odwołująca się do semantyki rymu zmienia tym samym całą wymowę wiersza.

W poetyce parnasistowskiej rym odgrywał bardzo ważną rolę. Świadczy o tym chociażby wielość dyskusji wśród parnasistów nad tym zagadnieniem $\mathrm{w}$ ich pracach teoretycznych. Najważniejszą rozprawą w tym zakresie jest Petit traité de poésie française Banville’a, w której rymowi zostały poświęcone dwa rozdziały. „Rym” jest tam określany jako słowo magiczne, obdarzone szczególną mocą ${ }^{48}$. Jest to też słowo najważniejsze, mające moc całego wersu: „[...] w wersie słyszymy tylko słowo wchodzące w skład rymu i to jedno słowo pracuje nad wytworzeniem zamierzonego przez poetę efektu" ${ }^{49}$.

Inną kategorią, bardzo ważną w poetyce parnasistów jest HARMONIA, o niej pisze też Norwid, między innymi w korespondencji z 1854 roku do Marii Trębickiej. W liście poeta przedstawia utwory poetyckie jako formy cechujące się proporcjonalną i racjonalną architekturą oraz powtarzalnością: „[...] poezja ma architekturę rozsądku swego, i rzeźbę profilu wiersza, i malarstwo światło-cienia, i muzykę powoju słów, i taniec powtarzanych i odbijanych strof [...]" (VIII: 209). Zastosowanie tej definicji harmonii jest szczególnie widoczne w poetyce opus magnum Norwida, czyli w Vade-mecum. Utwory cyklu zostają określone jako perły, które uwodzą odbiorcę pięknem swojej struktury, by nakłonić go do deszyfracji trudnych i niespójnych często treści.

Wiersz Ironia z cyklu Vade-mecum, mówiący o ironicznym zgrzycie w kontekście formy, tego „Zgrzytu” w swojej konstrukcji nie przekazuje. Zbudowany jest z pięciu czterowersowych strof o rymach przeplatanych. Można wręcz mówić w przypadku tego utworu o ironicznej kompozycji w stosunku do przekazywanych treści. To zjawisko znajduje wytłumaczenie w przekonaniu Norwida, że sztuka poetycka powinna być poddana rygorom oraz dyscyplinie kompozycji ${ }^{50}$. Wolność bowiem w tym zakresie sprawi, że przekaz poetycki stanie się konstruktem zdeformowanym i niezdolnym do wyrażenia czegokolwiek: „Bo cała siła w formie jest” (VIII: 18) - pisał Norwid w liście do Antoniego Celińskiego.

Zachowanie klasycznej, harmonijnej kompozycji nie kłóci się mimo wszystko z predylekcją poety do wieloznaczności, fragmentaryczności.

47 Zob. A. Brajerska-Mazur, O przekładzie na język angielski wierszy Norwida „Śmierć”, „Do zeszłej...”, „Finis”, „Pamiętnik Literacki” 1966, z. 4, s. 225.

48 Zob. Th. de Banville, Petit traité de poésie française, s. 44.

49 Tamże, s. 42.

50 Zob. E. Kasperski, Wolność i forma. Dwa bieguny liryki Norwida, w: Liryka Cypriana Norwida, red. P. Chlebowski, W. Toruń, Lublin 2003 , s. 98. 
Utwory są tak skonstruowane, by nie rozpadły się pod naporem niespokojnych, pełnych dramatycznego napięcia refleksji. Jak pisze Zygmunt Dokurno: „Do wykształcenia prostych, silnych zwartych konstrukcji zmierzały poszukiwania artystyczne Norwida, gdyż tylko takie «formy» mogły wytrzymać napór niespokojnego intelektu" ${ }^{51}$. Takie zabiegi kompozycyjne określić można jako paralelizm kontrastowy; jak pisze Edward Kasperski: „Jednym ze stosowanych przezeń [Norwida - A.K.] typowych chwytów jest paralelizm kontrastowy, mający na względzie uzmysłowienie różnicy czy nawet przeciwieństwa pomiędzy odpowiednimi cechami pozytywnymi i negatywnymi definiowanego zjawiska" ${ }^{2}$.

Wymienione w liście do Marii Trębickiej składniki poezji Norwida, zachowanie odpowiednich proporcji, symetria budowy, były ważne również dla parnasistów. Termin „harmonia” bardzo często występuje w ich dziełach. W Petit traité de poésie française poezja została przyrównana do rodzącej się istoty zawierającej w sobie naturalną harmonię: „Narodzona wolna, żywa i harmonijnie zorganizowana jak wszystkie istoty poezja francuska” ${ }^{53}$. Dążenie do harmonii stylu jest widoczne również w twórczości Leconte’a de Lisle’a, na co zwraca uwagę Edmond Estève: „W Khironie [...] Troska o równowagę proporcji jest zawsze istotna. [...] [W Niobe] równowaga jest zachowana przez symetrię części. W La Légende des Nornes trzy stare kobiety siedzące na korzeniach jesionu Yggdrasill wypowiadają się kolejno, ich wypowiedzi zawierają mniej więcej równą liczbę wersów" ${ }^{54}$.

W utworach parnasistów francuskich pojawia się też jednak kwestia dysharmonii pomiędzy treścią a formą utworów. Wiersz Leconte’a de Lisle'a Aux Modernes jest sonetem mówiącym o śmierci i moralnym wyniszczeniu człowieka. W ostatniej strofie utworu czytamy:

Nie widząc przeznaczenia dla dni swych i nocy,

Zapędzeni w pustkowie najwyższej niemocy,

$\mathrm{Z}$ napuchniętą kieszenią zdechniecie w podłości. ${ }^{55}$

Forma sonetu wydaje się nieadekwatna do przekazywanych treści. W wierszu mowa przecież o śmierci ludzkości, o niemocy, o wyniszczeniu

51 Z. Dokurno, Kompozycje utworów lirycznych Norwida (do roku 1852), Poznań 1965, s. 128; por też D. Plucińska, Sentencjonalność Norwida. O Vade-mecum i „trylogii włoskiej", Lublin 2005, s. 204.

52 E. Kasperski, Świat wartości Norwida, Warszawa 1981, s. 123.

53 Th. de Banville, dz. cyt., s. 99.

54 E. Estève, Leconte de Lisle. L'homme et l'oeuvre, Paris 1920, s. 196.

55 L. de Lisle, Do współczesnych, przeł. M. Zięba, w: tegoż, Poezje, wyb., oprac. i wstęp J. Strasburger, Warszawa 1980, s. 123. 
moralnym - i wszystko to zostało przedstawione w niezwykle klasycznym, harmonijnym, proporcjonalnym gatunku, jakim jest sonet. Zderzenie to wywołuje podobny efekt, jak chociażby w przypadku Norwidowego wiersza Ironia.

Przedstawione w niniejszym artykule zbieżności wątków myśli Norwida z estetyką parnasistowską wskazują więc, że Norwid, czego norwidystyka zdaje się nie doceniać, czytał takie same czasopisma i publikował w tych samych periodykach, co parnasiści francuscy. Poetę zajmowały również podobne kwestie, jakie były ważne dla tej grupy francuskich poetów. Oczywiście, nie jest to wystarczająca przesłanka, by określić autora Vade-mecum mianem parnasisty. Nie można jednak ignorować faktu, że funkcjonowanie przez bardzo długi czas we wspólnej przestrzeni literackiej, kształtowanie przez takie same wzorce nie było obojętne dla dzieła Norwida i wywierało nań określony wpływ, którego ślad jest w korespondencji poety wyrazistszy niż w innych formach jego twórczości.

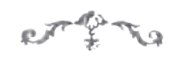

A B S T R A T

\section{Cyprian Norwid's Attitude Towards Parnassianism in THE Light OF His OpINIONS}

The article shows the relationship of Norwid and his work towards French Parnassianism. As is clear from the letters, Norwid regularly read two newspapers, which published the Parnassians: L'Artiste, where in 1856 Théophile Gautier published his manifesto, and Revue de deux mondes. They published, among others, reviews of the Les Cariatides collection by Theodore de Banville's, or of Stances et Poèmes by Sully Prudhomme, as well as poetry of Leconte de Lisle. The creative outputs of both Norwid and Parnassians display many common features, such as the role of rhyme and harmony, as well as the demand that poetry should not be subordinated to the personal goals of man. In the letters Norwid stressed the role of work on composition, requiring the use of specific tools (the theme of the chisel is a frequently recurring one). French Parnassians, Gautier in particular, also employed sculptural imagery to emphasise the need for effort in the creation of the work.

\section{KE Y W O R D S}

Cyprian Norwid, parnassianism, poetic imagination, Polish poetry, Théophile Gautier 